\title{
Endophytic fungi as potential biocontrol agents of Phytophthora palmivora in the cocoa plant
}

\author{
AGNES V. SIMAMORA ${ }^{\star}$, MAYAVIRA V. HAHULY, JULINDA BD. HENUK \\ Faculty of Agriculture, Universitas Nusa Cendana, Jl. Adisucipto Penfui, Kupang-NTT, `email: asimamora@staf.undana.ac.id
}

Manuscript received: 20 February 2021. Revision accepted: 17 April 2021.

\begin{abstract}
Simamora AV, Hahuly MV, Henuk JBD. 2021. Endophytic fungi as potential biocontrol agents of Phytophthora palmivora in the cocoa plant. Biodiversitas 22: 2601-2609. In Indonesia, the cocoa tree is one of the essential cultivation crops for farmers. Despite the importance of cocoa cultivation in Indonesia's economy, the productivity of this crop has declined. Cocoa black pod disease caused by Phytophthora palmivora (Butl.) is one of the most severe diseases affecting this crop worldwide, with average annual losses above $40 \%$. Instead of using manufactured chemicals, biological control is an effective and eco-friendly alternative control measure against plant pathogens. This work aimed to assess the potential of endophytic fungi isolated from healthy cocoa pods to control Phytophthora palmivora in vitro and in vivo. Endophytic fungal isolates were classified based on the morphological characteristics of their cultures and reproductive structures. All isolates found were tested to inhibit P. palmivora in the dual culture method, and the best 10 isolates were continued for detached pod assay. Then, the best five isolates (Aspergillus4, Aspergillus5, Aspergillus6, Fusarium6, Ramichloridium sp.) were evaluated for their capability to reduce $P$. palmivora in cocoa seedlings and in the field plants. Aspergillus, Fusarium, and Ramichloridium showed maximum activity against $P$. palmivora in dual culture, pod, and seedling assays. Nevertheless, when all these five isolates were applied in the field, they did not suppress the disease development.
\end{abstract}

Keywords: Aspergillus, cocoa, endophytic fungi, Fusarium, Ramichloridium, Phytophthora palmivora

\section{INTRODUCTION}

Cocoa is one of the most attractive plants for farmers around the equator due to the specific climate and inevitability imperative of profits over in the long term. Indonesia's equatorial climate, with its soil fertility, offers the best geographic conditions for the cultivation of cocoa trees. Witjaksono and Asmin (2016) stated that over 70\% of Indonesian cocoa production is focused on Sulawesi Island. Outside Sulawesi, the cocoa production regions are located in North Sumatra, West Java, and Papua, Bali, Flores, and other islands. Cocoa trade offers the primary source of salaries for more than $1,400,000$ smallholder growers and their households in Indonesia.

Indonesia's export value of processed cocoa products during January-June 2020 amounted to 549 million USD, an increase of 5.13 percent compared to the same period in 2019. Despite the contribution of cocoa farming in the Indonesian economy, cocoa production has gradually declined from 410.000 tonnes in 2012/2013 to 290.000 tons in $2019 / 2019$ and to 200.000 tonnes in 2020 , affecting this country downgraded from the $3^{\text {rd }}$ to $5^{\text {th }}$ and then to the $6^{\text {th }}$ highest cocoa producing country in the world (Sella and Fardah 2020; Praseptiangga et al. 2020).

The decline in cocoa productivity can be attributed to low farm management practices, old trees, and the incidence of pests and diseases (Wardhany and Adzim 2018). One of the most harmful diseases for cocoa cultivation worldwide, including in Indonesia, is black pod rot disease caused by Phytophthora palmivora. This pathogen attack on cocoa plantations has caused yield losses of $20 \%-40 \%$ worldwide, and the yield loss increased, especially in areas with high rainfall and humidity (Villamizar-Gallardo et al. 2017; Perrine-Walker 2020). In Indonesia, losses due to this disease can reach up to $90 \%$, especially during the rainy season (Gassa et al. 2016). Besides pod, P. palmivora also infect bark, flower cushions, stem, and branch causing cankers. Phytophthora canker's importance is perhaps underrated, as cankers diminish plant vigor and fruit-bearing capability, therefore decreasing harvest. Stem cankers may also develop a significant source of inoculum for pod rot. Likewise, in wet conditions, $P$. palmivora produces seedling and leaf blight (Guest 2007). Seedling blight often develops wilting of stems and leaves, defoliation, and finally death within one week after inoculation (Nur'Aini et al. 2016), and the disease can cause total loss if not managed (Peter and Chandramohanan 2014).

Currently, incorporated pest and disease control methods such as phytosanitation, pruning, chemical fungicide, resistant cultivars, and biological agents are recommended to suppress pod rot disease. Still, this disease remains a problem worldwide (Hanada et al. 2009; Rubiyo and Amaria 2013). Conventional chemical control of black pod rot disease can be costly, unproductive, and risky for both ecological and human safety. As part of integrated pest management, biological control has been recommended as the best natural, environmentally friendly remedy (De Silva et al. 2019).

One of the promising new agents in the biological control of plant diseases is fungal endophytes. Fungal endophytes are defined as fungi residing in plant tissue and 
do not show disease symptoms (Chitnis et al. 2020). These endophytic fungi protect their hosts from harmful organisms and unfavorable environments by producing bioactive secondary metabolites directly and indirectly (Fadiji and Babalola 2020a). According to Nur Amin (2013), Nur Amin et al. (2014 and 2015), endophytic fungi protect their host plant against pest and pathogen, i.e., rootknot nematode Meloidogyne spp., cocoa pod borer Conopomorpha cramerella, and Oncobasidium theobromae, the causal agent of vascular streak dieback disease on the cocoa seedling. Similarly, Mejía et al. 2008 reported that endophytic fungi could control three primary diseases of cocoa, i.e. black pod rot disease caused by Phytophthora spp.; frosty pod disease caused by Moniliophthora roreri; and witches broom disease caused by Crinipellis perniciosa. In some cases, fungal endophytes inhibited the growth of cocoa pathogens both in laboratory and field studies (Hanada et al. 2009, 2010). All results emphasized that fungal endophytes are important as a contemporary biological control agent for controlling pathogenic diseases of cocoa. This current work emphasis on (i) assessing and identifying endophytic fungi isolated from healthy cocoa pods collected from small scale cocoa farmings in three sub-districts of Sikka District, East Nusa Tenggara (ENT), Indonesia, (ii) evaluating the antagonistic effect of selected endophytes against Phytophthora palmivora in vitro and in vivo.

\section{MATERIALS AND METHODS}

\section{Isolation of endophytic fungi}

Three-month-old of healthy cocoa pods were collected and kept in a sterile plastic container. All pods were brought to the laboratory benches for processing within 48 $\mathrm{h}$ after harvesting. Exterior cleansing was carried out according to Myrchiang et al. 2014. The pods were first cleaned by running tap water to eliminate rubbish usually abiding on pods' surface. After that, all pods were disinfected in 70\% ethanol for 1-3 minutes followed by $4 \%$ sodium hypochlorite $(\mathrm{NaClO})$ solution for 3-4 minutes, then rinsed with $70 \%$ ethanol for 2-5 seconds and lastly washed twice with sterile distilled water for one minute to eradicate all the disinfectants. The disinfected pods were sliced into small pieces of $5 \mathrm{~mm}$ x $5 \mathrm{~mm}$ with a sterilized blade. Each sample was blot dried out under sterile conditions. Four to six slices of the cutting pod were put in Petri dishes containing potato dextrose agar (PDA) medium with streptomycin $\left(100 \mathrm{mg} \mathrm{L}^{-1}\right)$. The composition of PDA was $200 \mathrm{~g} \mathrm{~L}^{-1}$ diced potatoes, $20 \mathrm{~g} \mathrm{~L}^{-1}$ dextroses, and $20 \mathrm{~g} \mathrm{~L}^{-}$ ${ }^{1}$ agar. The medium was prepared by adding the potato infusion (boiled filtrate of diced potatoes) along with dextrose and agar and sterilized by autoclaving at $121^{\circ} \mathrm{C}$, $15 \mathrm{lb}$ pressure for $15 \mathrm{~min}$. The inoculation was carried under a laminar airflow chamber, and after the inoculation, the dishes were labeled accordingly and incubated at laboratory benches at $28 \pm 2^{\circ} \mathrm{C}$.

The Petri dishes were observed daily to assess the fungal growth. After several days of incubation, purity of each isolate was assessed by examining the colony morphology. All the isolates were purified and pure culture was maintained in PDA slant tubes.

\section{Characterization of endophytic fungi}

All the endophyte isolates were characterized based on their macroscopic and microscopic features and their reproductive structures under a microscope (10X and 40X) using routine procedures (Barnett and Hunter 1998; Watanabe 2010). Macroscopic observation was based on the fungal colony's characteristics on agar medium such as colony diameter, color, texture, reverse side, margins, and pigment production (Olokkaran et al. 2019). Microscopic features were monitored for the presence or absence of conidia, conidia shape and size, conidial arrangement, conidiophores, hyphae (septate or non-septate). Identification was performed by wet mount technique in which the fungal colonies were stained using lactophenol cotton blue.

\section{Subculturing of Phytophthora palmivora}

Phytophthora palmivora isolate was obtained by Plant Disease Laboratory, Universitas Nusa Cendana. Phytophthora palmivora was isolated from diseased cocoa pods (with symptoms of blackish-brown spots). The isolation procedure was as follows: diseased cocoa pods were surface sterilized using $70 \%$ ethanol. Then, the outer skin of cocoa pods was removed using a sterile knife. At the edge between diseased and healthy tissue, $0.5 \times 0.5 \mathrm{~cm}^{2}$ of pulp was taken, then mixed in $2 \%$ water agar (WA) media. The culture was then incubated for three days until hyphae grew on the surface of the tissue. The growing hyphae were transferred to PDA media, incubated at room temperature, then purified and identified.

\section{Evaluation of antagonistic effects of endophytic fungi}

The antagonistic activity of fungal endophytes was evaluated based on the technique of Mejía et al. 2008. The types of interaction between endophytes and $P$. palmivora were evaluated $60 \mathrm{~h}$ after they were incubated in the Petri dishes. The interactions observed were antibiosis, competition, and mycoparasitism. All endophytic fungi isolated were tested for their antagonism against Phytophthora palmivora by using dual culture technique as explained by Myrchiang et al. 2014 with minor modifications. The steps were as follows: (i) $5 \mathrm{~mm}$ diameter of mycelial plugs of fungal endophytes and $P$. palmivora were plated on the reverse edge of the PDA plate. (ii) The Petri dishes were set in five replicates. For control, P.palmivora was plated with sterile agar plugs. (iii) The Petri dishes were arranged in laboratory benches at $25 \pm 2^{\circ} \mathrm{C}$ for seven days. (iv) The growth of $P$. palmivora was assessed against all the fungal endophytes. Data on the growth of the P.palmivora and fungal endophytes were observed every day. (v) The inhibition percentage of radial growth of $P$. palmivora by endophytes was computed using the formula:

$$
\text { Inhibition percentage }(\%)=(\mathrm{R} 1-\mathrm{R} 2) \mathrm{R} 1^{-1} \times 100
$$

Where $\mathrm{R} 1$ = radial growth of $P$. palmivora in control Petri dish; R2 $=$ radial growth of $P$. palmivora towards the 
antagonist in test Petri dish. The percentage of inhibition was analyzed using analysis of variance (ANOVA) and continued with least significant difference (LSD) test.

\section{Testing the ability of endophytic fungi to reduce Phytophthora palmivora lesions on detached cocoa pods}

Based on in vitro antagonisms test, 10 endophytic fungal isolates were chosen for the detached cocoa pods test. Approximately four-month-old cocoa pods were collected from small-scale cocoa farms in Nebe and Munerana Villages, Sikka, ENT, Indonesia. The day before the pods were collected, the farm was checked and verified to be healthy without any injury. All the collecting pods were brought to the laboratory for further processing. All endophytic fungal spores were collected from seven-dayold cultures plated on PDA. The conidia suspension was prepared by cleansing the cultured dishes with sterile distilled water. The concentration of conidia was adjusted using a hemocytometer $1 \times 10^{6}$ spores $\mathrm{mL}^{-1}, 2 \%$ tween 20 LC was added to obtain a homogeneous suspension (Hanada et al. 2010), and coconut oil was included as an adhesive (Hanada et al. 2010; Sriwati et al. 2015). The conidia suspension was applied to the entire pod surfaces using a garden sprayer. Sprayed pods were kept in a plastic container at $25 \pm 2^{\circ} \mathrm{C}$ for 24 hours to maintain moisture. Twenty-four $\mathrm{h}$ after applying endophytic fungi isolates, pods were infected with $P$. palmivora in this way. The epicarp of each pod was cut at four dots with a distant of 1 $\mathrm{cm}$ using a sterilized scalpel. The exposed parts were sealed with $5 \mathrm{~mm}$ diameter agar plug taken from 1-week old $P$. palmivora culture. Pods were kept for seven days at $25 \pm 2^{\circ} \mathrm{C}$ in a $40 \mathrm{~cm} \times 30 \mathrm{~cm}$ plastic container. The treatments were arranged in a completely randomized design with five replicate pods. One pod inoculated with one fungal endophyte. Observations were made on disease symptoms and spot diameter of $P$. palmivora on the surface of the cocoa pods. The experiment was conducted twice. Data from the two experiments were averaged and analyzed. Spot diameter was analyzed using Anova and followed by LSD test.

\section{Screen-house experiment}

Three-month-old healthy cocoa seedlings were collected from small scale farming in Munerana Village, Sikka District, ENT, Indonesia. Seedlings were grown in a $5 \mathrm{~kg}$ polybag filled with sterilized field soil and compost (2:1) and were irrigated daily but the above-ground parts were kept waterless. Five chosen fungal endophytes (Aspergillus4, Aspergillus5, Aspergillus6, Fusarium6, Ramichloridium sp.) were inoculated on cocoa leaves. All five endophytes showed good antagonistic ability to inhibit $P$. palmivora in dual culture and pod assays. The spore suspensions of all endophytic isolates were prepared as described before. Spores were sprayed on all aerial parts of the plant in the late afternoon by a garden sprayer until the whole seedlings were soaked. Uninoculated seedlings were applied with sterilized water. The seedlings were set on benches and arranged in a randomized block design with five replicates. High relative humidity was maintained in the screened house for $48 \mathrm{~h}$ following by placing a wet cloth between the seedlings (Mejía et al. 2008).

Two weeks after the endophytes application, the seedlings were inoculated with $P$. palmivora. Phytophthora palmivora sporangia were collected from black pod rot disease according to the procedure of Sriwati and Muarif (2012). The concentration of P. palmivora sporangia was adjusted to $1 \times 10^{6}$ sporangia $\mathrm{mL}^{-1}$ using hemocytometer. The sporangia suspension was applied to the seedlings by a garden sprayer. After the application, the plants were protected with a plastic cover to retain moisture for one day (Sriwati et al. 2015). Two weeks after the application of $P$. palmivora, seedlings were monitored for disease symptoms and disease incidence (DI). DI was calculated as follows: $\mathrm{DI}=\left(\mathrm{n} . \mathrm{N}^{-1}\right) \times 100 \%$, with $\mathrm{n}=$ number of infected seedlings and $\mathrm{N}=$ number of observed seedlings. The experiment was conducted twice. The average data from the experiment were used for analysis. Disease incidence was analyzed using Anova and continued with LSD test.

\section{Field trial}

Five endophytic isolates formerly assessed under screen house settings were selected for the field trial. The trial was conducted in a cocoa farm Wolomotong Village, Sikka Regency, ENT, where biological agents were never applied. The garden used was owned by a farmer whose cocoa pods were heavily infected with $P$. palmivora. The experimental pods were 3 to 4 months old attached to the tree. The pods used were categorized into four groups of severity: (i) $0 \%$ (healthy); (ii) Pod severity $>10 \leq 25 \%$; (iii) Pod severity $>25<50 \%$; and (iv) Pod severity $\geq 50 \%$. Inoculation of fungal endophytes on cocoa pods was conducted according to the predetermined category. Different pod categories could be fixed in one tree, but only one endophyte was applied in one tree. Distance between cocoa trees was $1.5-3.0 \mathrm{~m}$. The treatment consisted of five isolates of endophytic fungi (Aspergillus4, Aspergillus5, Aspergillus6, Fusarium6, Ramichloridium sp.), which were sprayed directly on the cocoa pods, with three replications (three pods). The spore suspensions $(1 \mathrm{x}$ $106 \mathrm{~mL}^{-1}$ ) of all endophytic isolates were prepared as described previously and applied to the pods surface until near overflow, using a garden sprayer. In this method, the amount of suspension sprayed on each pod was $40-50 \mathrm{~mL}$, taking into account the cocoa pod's regular size. The cocoa pods were covered with clear plastic to maintain the humidity, placed $24 \mathrm{~h}$ before applying treatments, and took off one day after that, tolerating the trial to be performed under normal field circumstances (Hanada et al. 2009). The healthy pods were inoculated with sterile water. Disease severity was recorded every week for four weeks.

\section{RESULTS AND DISCUSSION}

\section{Isolation and characterization of endophytic fungi from cocoa pods}

Total of 25 isolates of endophytic fungi were isolated from healthy cocoa pods. All isolates were classified to the genera taxon, but one isolate remains unidentified. The isolates found were seven isolates of Fusarium, six isolates 
of Aspergillus, three isolates of Gliocladium, three isolates of Cylindrocladium, three isolates of Mortierella, one isolate of Ramichloridium, and one isolate of Rhizoctonia.

Result showed that all fungal isolates were basically belonging to Class 2 endophytes, Ascomycota (96\%) and Basidiomycota (4\%), but because they only exhibited asexual form during examination, all isolates belonged to the Deuteromycota group or imperfection fungi. Generally, fungal endophytes are grouped into clavicipitaceous endophytes (C-endophytes) and the non clavicipitaceous endophytes (NC-endophytes. These two main groups of endophytic fungi show variation in evolutionary correlation, taxonomy, plant hosts, and ecological roles. The C-endophytes abide in some grasses while NC-endophytes are attained from vascular and non-vascular plant species (Jain and Pundir 2017). NC-endophytes are very widespread, they have been regained from each major ancestry of terrestrial floras and all continental ecosystems, containing agroecosystems and biomes varying from tropics to tundra. NC-endophytes are divided into three functional classes (Class 2, $3 \& 4$ endophytes) based on host colonization model, transmission methods between host generations, in planta biodiversity ranks, and ecological role (Lugtenberg et al. 2016). The assorted class 2 endophytes include both Ascomycota and a small number of Basidiomycota (Abo Nouh 2019).

In this study, Fusarium and Aspergillus were the most prevalent genera with $7(28 \%)$ and $6(24 \%)$ isolates found, respectively. The frequency of these genera was inconsistent with findings of other research (Nur Amin et al. 2014), even though the ratios were different because the test plant for sampling was different. Two genera i.e. Ramichloridium and Rhizoctonia obtained as individual isolates.

Species of the genus Ramichloridium show various morphological characteristics and lifestyles, such as plant pathogens, commensals, and saprophytes (Kirschner and Piepenbring 2014), but Zheng et al. (2020) reported that $R$. endophyticum was obtained as an endophyte from an aquatic macrophyte Potamogeton pectinatus. Xie et al. (2016) also reported that a Class 2 endophytes, Ramichloridium cerophilum isolated from the leaf of Sonchus oleraceus, has displayed the ability to improve biomass of Chinese cabbage, a nonmycorrhizal plant. Fitriarni and Kasiamdari (2018) stated that Rhizoctonia was obtained as a fungal endophyte from leave and stem of Calopogonium mucunoides and Rashmi et al. (2019) informed that Rhizoctonia spp. were isolated as endophytic fungi from several plants such as Fragaria vesca, Brassica napus, Taxus mairei, and Canarium ovatum.

\section{In vitro antagonistic assay}

All the endophytic fungi tested against $P$. palmivora showed in vitro antagonism. The competition was the most common mode of action against $P$. palmivora (Table 1). This assay exhibited that all fungal endophytes examined had an effective antagonism to suppress $P$. palmivora, the cocoa's black rot pod pathogen. All the tested antagonists noticeably inhibited the radial growth of the pathogen. In the control plate ( $P$. palmivora minus endophytes), $P$. palmivora grew rapidly and colonized the entire plate within seven days, whereas in dual culture $P$. palmivora takes longer time to develop. The percentage of inhibition of radial growth of $P$. palmivora by all the tested fungal endophytes was significantly different. Fusarium6 was recorded to be the best aggressive isolate and constrained the radial development of the $P$. palmivora, followed by Aspergillus5, Ramichloridium sp., Fusarium5, and Gliocladium3.

The inhibition of $P$. palmivora by endophytic fungi varied substantially, due to the different mechanisms of each isolate. Fadiji and Babalola (2020a) stated that the mechanism of inhibiting pathogens growth by endophytic fungi can be by direct parasitizing of the pathogens, production of antibiotics, competition for place and food, production of enzymes, and initiation of plant resistance responses. Endophytic fungi showed inhibition against $P$. palmivora by various mechanisms, namely competition $(15$ isolates $=60 \%)$, antibiosis ( 8 isolates $=$ $32 \%$ ), and mycoparasites ( 2 isolates $=8 \%$ ) (Table 1 , Figure 1). In a competition mechanism, the growth of endophytic fungi was faster than that of $P$. palmivora so that all the space was filled with endophytic fungi, and the growth of $P$. palmivora was inhibited (Figures 1.B and 1.C). The antibiosis mechanism can inhibit pathogens by producing antibiotics, enzymes, and toxins (Figures 1.A). In mycoperitism, endophytic fungi destroyed or deformed the cell walls of $P$. palmivora (Figure 1.D).

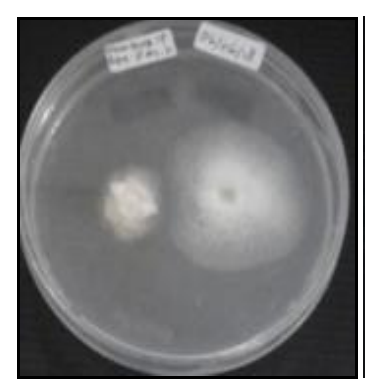

Fusarium4

A

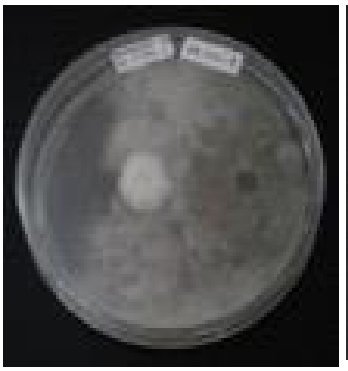

Aspergillus4

B

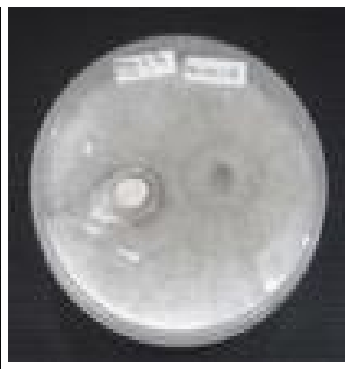

Aspergillus6

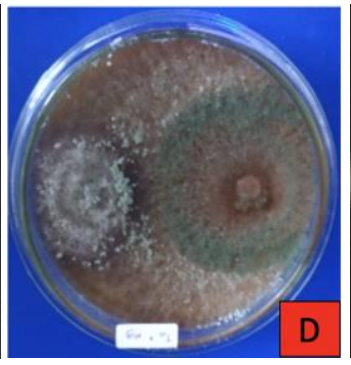

Gliocladium2

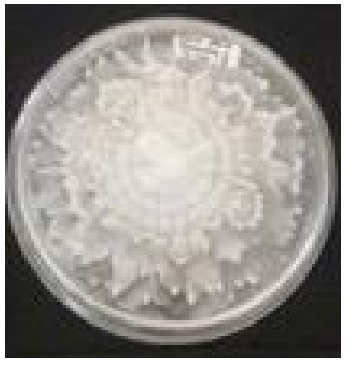

P. palmivora

Figure 1. Inhibition growth of four endophytic fungi from cocoa pods to Phytophthora palmivora. A= mechanism of antibiotic; B and $\mathrm{C}=$ mechanism of competition; $\mathrm{D}=$ mechanism of mycoparasite. Pictures A-D were taken seven days after inoculation of both endophytic fungi and P. palmivora in the Petri dishes, E= control, seven- day old Phytophthora palmivora 
The mechanism of inhibition of $P$. palmivora by endophytic fungi due to antibiosis, which was characterized by a clear zone around endophytic fungi. The mechanism of antibiosis may include the production antibiotics or secretion of lytic enzymes (Fadiji and Babalola 2020a). Furthermore, Fadiji and Babalola (2020a) stated that metabolites produced by endophytic fungi are categorized into separate groups such as alkaloids, terpenoids, phenols, steroids, and polyketides.

Sufficient data are available that fungal endophytes comprise an essential role in host-plant physiology. They accept food, security, and dissemination from their host, whereas host plants are profited from this symbiosis as well (Fadiji and Babalola 2020a). Endophytes offer shelter to their hosts from destructive organisms and support their hosts to acclimate in varied adverse environments. Methods opted by endophytic fungi for plant growth stimulation are competition, phosphate solubilization, and the production of siderophore, phytohormone, cell wall-lysing enzymes, and antibiotics (Vyas and Bansal 2018; Fadiji and Babalola 2020a).

These in vitro results indicated that Fusarium spp., Aspergillus spp., Ramichloridium sp, and Gliocladium spp. could inhibit the growth of $P$. palmivora. Other investigations have verified the capability of these endophytic fungi to control pathogens. Gautam et al. (2013) concluded that endophytes Aspergillus niger and $A$. flavus isolated from Cannabis sativa prevent the growth of two common phytopathogenic fungi, Colletotrichum gloeosporioides, and Curvularia lunata. Similar result from Wei et al. (2019) also revealed that Fusarium solani, a fungal endophyte strain isolated from cotton, exhibits protection against Verticillium dahliae, a soilborne pathogen causing verticillium wilt of cotton, one of the most severe diseases of cotton worldwide. Gliocladium isolated from the Eucryphia cordifolia releases a combination of volatile organic compounds toxic to Pythium ultimum and Verticillium dahliae (Stinson et al. 2003). Ramichloridium sp. obtained from indigenous Euterpe precatoria, performed a unique capability to manage anthracnose disease caused by Colletotrichum gloeosporioides (Peters et al. 2020).

Testing endophytic fungi ability to reduce Phytophthora palmivora lesions on detached cocoa pods

Result showed that all tested isolates suppressed $P$. palmivora infection compared to control (Table 2). The strongest suppression was exhibited by Aspergillus 6 but insignificantly different with Aspergillus 4 and Fusarium6 isolates. All endophytic fungi use different methods of antagonism against $P$. palmivora. Fungal endophytes protect plants by employing both direct and indirect mechanisms. There are three primary methods by which endophytic fungi possibly develop plant defense to phytopathogens (Fadiji and Babalola 2020a). First, the endophytes decline the pathogens by parasitizing them directly or other antimicrobial complexes, or by producing phytoalexin, and biocidal compounds. Second, endophytes defeat pathogens by confronting space and food, or by supplying enzymes that attack the cell elements of pathogen. Third, endophytes suppress pathogens by secreting antibiotic elements (Myrchiang et al. 2014). The antagonistic effect of Aspergillus spp., Ramichloridium sp., Gliocladium sp., and Fusarium sp. isolates in this study may be due to the combination of all three mechanisms (Myrchiang et al. 2014; Fadiji and Babalola 2020a).

The capability of endophytic fungi to reduce the growth of pathogens was confirmed by previous studies. Hanada et al. (2010) concluded that the use of endophytic fungi against $P$. palmivora could suppress the development of pathogens in cocoa pods. Furthermore, Sreeja et al. 2016 stated that Fusarium sp. had the potential to control Phytophthora capsici, causing foot rot disease of black pepper. de Lamo and Takken (2020) revealed that nonpathogenic Fusarium oxysporum induced resistance against numerous fungal pathogens. Meanwhile, Sriwati et al. (2015) concluded that endophytic Trichoderma virens reduced the expansion of $P$. palmivora lesions on detached cocoa pods up to $77 \%$. Similar finding was also informed by Abdallah et al. (2015), in which they examined nine isolates of Aspergillus spp., as biological control agents against $P$. erythroseptica, the causal organism of pink rot disease of potato.

Table 1. The percentage of inhibition and the mechanism of antagonism of endophytic fungi against Phytophthora palmivora in dual culture method.

\begin{tabular}{|c|c|c|c|c|}
\hline \multirow[b]{2}{*}{ Endophytic fungi } & \multirow{2}{*}{$\begin{array}{c}\text { Mean \% } \\
\text { inhibition }\end{array}$} & \multicolumn{3}{|c|}{ Mechanisms of antagonism } \\
\hline & & Antibiosis & Competition & $\begin{array}{c}\text { Myco- } \\
\text { parasitism }\end{array}$ \\
\hline Aspergillus 1 & 58.98 cde & & + & \\
\hline Aspergillus 2 & $57.58 \mathrm{~cd}$ & & + & \\
\hline Aspergillus 3 & $79.33 \mathrm{~g}$ & + & & \\
\hline Aspergillus 4 & $80.00 \mathrm{f}$ & & + & \\
\hline Aspergillus 5 & $88.67 \mathrm{i}$ & & + & \\
\hline Aspergillus6 & $80.67 \mathrm{gh}$ & & + & \\
\hline Cylindrocladium 1 & $71.01 \mathrm{f}$ & & + & \\
\hline Cylindrocladium 2 & $47.33 \mathrm{~b}$ & + & & \\
\hline Cylindrocladium 3 & $50.33 \mathrm{~b}$ & + & & \\
\hline Fusarium 1 & $61.67 \mathrm{de}$ & & + & \\
\hline Fusarium 2 & $58.52 \mathrm{~cd}$ & & + & \\
\hline Fusarium 3 & $56.54 \mathrm{c}$ & & & + \\
\hline Fusarium4 & $74.00 \mathrm{f}$ & + & & \\
\hline Fusarium5 & $85.33 \mathrm{hi}$ & + & & \\
\hline Fusarium6 & $88.83 \mathrm{i}$ & & + & \\
\hline Fusarium 7 & $80.60 \mathrm{gh}$ & & + & \\
\hline Gliocladium 1 & $73.77 \mathrm{f}$ & & + & \\
\hline Gliocladium 2 & $63.56 \mathrm{e}$ & & & + \\
\hline Gliocladium 3 & 84.00 ghi & & + & \\
\hline Mortierella 1 & $39.33 \mathrm{a}$ & & + & \\
\hline Mortierella2 & $39.00 \mathrm{a}$ & + & & \\
\hline Mortierella 3 & $62.00 \mathrm{de}$ & + & & \\
\hline Ramichloridium sp. & $87.67 \mathrm{i}$ & & + & \\
\hline Rhizoctonia sp. & 60.50 cde & + & & \\
\hline Unknown & $58.52 \mathrm{~cd}$ & & + & \\
\hline
\end{tabular}

Note: superscript letters denote significant difference (LSD 0.05) among the treatment means. 
Table 2. Spot diameter of cocoa pod after treatment with endophytic fungi following inoculated with P. palmivora.

\begin{tabular}{lc}
\hline Endophytic fungi & Spot diameter of cocoa pod (cm) \\
\hline Aspergillus 3 & $3.70 \mathrm{e}$ \\
Aspergillus 4 & $2.03 \mathrm{ab}$ \\
Aspergillus 5 & $2.57 \mathrm{bc}$ \\
Aspergillus6 & $1.80 \mathrm{a}$ \\
Fusarium 4 & $2.90 \mathrm{~cd}$ \\
Fusarium5 & $2.70 \mathrm{~cd}$ \\
Fusarium 6 & $2.00 \mathrm{ab}$ \\
Fusarium 7 & $3.80 \mathrm{e}$ \\
Gliocladium 3 & $3.30 \mathrm{de}$ \\
Ramichloridium sp. & $2.73 \mathrm{~cd}$ \\
Control & $6.47 \mathrm{f}$ \\
\hline Note: superscript letters denote significant difference (LSD 0.05)
\end{tabular}

Note: superscript letters denote significant difference (LSD 0.05) among the treatment means.

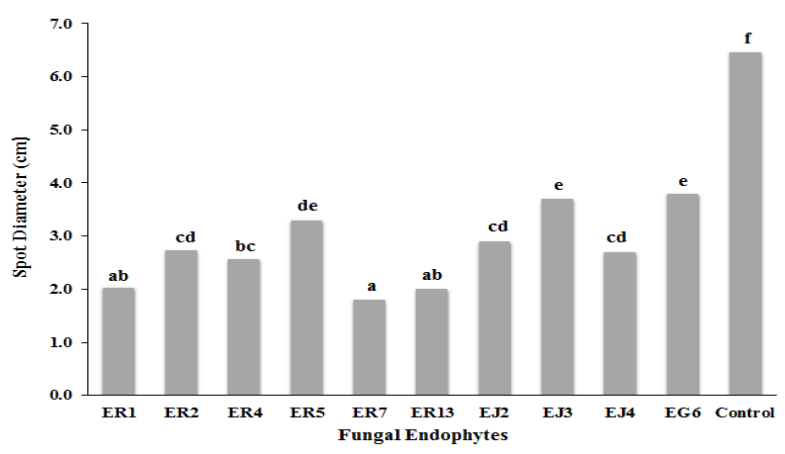

Figure 2. The effect of fungal endophytes against $P$. palmivora on cocoa pods $(\mathrm{ER} 1=$ Aspergillus $4, \mathrm{ER} 2=$ Ramichloridium $\mathrm{sp}$, ER4=Aspergillus5, ER5= Gliocladium3, ER7= Aspergillus6, $\mathrm{ER} 13=$ Fusarium6, EJ2 $=$ Fusarium 4, EJ3=Fusarium5, EJ4= Aspergillus3, EG6= Fusarium7). Different superscript letters above the bar indicate statistically significant differences by LSD post hoc test (0.05).

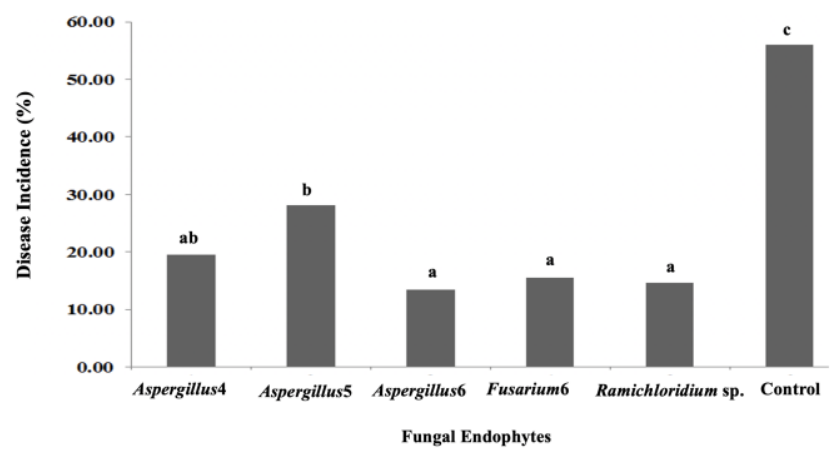

Figure 3. Mean disease incidence (\%) of cocoa leaves inoculated with $P$. palmivora following the treatment of endophytic fungi. Different in letters above the bar indicate statistically significant differences by LSD post hoc test (0.05).
The ability of Aspergillus spp. to reduce the growth of P. palmivora lesions on detached cocoa pods is possibly due to their ability to produce a lot of derivative metabolites with various biological importance, such as antipathogens activities (El-hawary et al. 2020). Additionally, Myrchiang et al. 2014 reported that Aspergillus fumigatus secreted aflatoxin, carcinogenic and mutagenic secondary metabolites that inhibited the growth of Phytophthora infestans in vitro.

\section{Screen-house experiment}

All isolates tested on cocoa seedlings notably reduced the disease incidence of $P$. palmivora on leaves compared to untreated (uninoculated) seedlings (Figure 3). Figure 3 revealed that Aspergillus6 isolate showed maximum inhibition against $P$. palmivora but did not differ significantly with Ramichloridium sp., Fusarium6, and Aspergillus 4 isolates. This result was slightly different from the pod trial. In the cocoa pod trial, Ramichloridium $\mathrm{sp}$. isolate alone demonstrated lower inhibition percentage (Figure 2) than the screen house trial. This difference may be because Ramichloridium sp. had different antagonistic modes. So, it is helpful to properly recognize the plantendophytes ecosystem model and classify the methods of collaboration of endophytes, plants, and phytopathogens to obtain practical biological control approaches (Mejía et al. 2008).

The first symptom on leaves was observed seven days after the inoculation of $P$. palmivora. Leaves had small necrotic spots with around $1 \mathrm{~mm}$, and as the infections continued, the necrotic lesions and leaf blight became more apparent. No symptoms observed on the stem. The disease incidence on the untreated control seedling was $56 \%$, and it significantly lower on the treated seedlings that ranged from $13.48 \%-28.07 \%$. In this seedling trial, preinoculation of endophytes was established to better colonization of the endophytes prior to the arrival of pathogenic $P$. palmivora. The activities of endophytes in limiting $P$. palmivora were confirmed by Mejía et al. 2008; Hanada et al. 2010; Sriwati et al. 2015; Harni et al. 2014. This experiment indicates that fungal endophytes obtained from infected cocoa pods restricted the growth of $P$. palmivora.

\section{Field trial}

Changes in disease severity of cocoa pods that occurred after application of endophytic fungi are presented in Table 4 and Figure 4. Table 4 shows that endophytic fungi application on cocoa pods did not reduce pod rot disease severity. Disease progression continues; even when cocoa pods were healthy at first, the disease can develop. There were many diseased pods in the garden so that the infection from the diseased fruit quickly spread to the healthy fruit. Even low severity fruit (10\% and 25\%) could rapidly increase in severity to $100 \%$ within four weeks. The disease severity is supposed to rely on three factors, the host plant, the pathogen virulence, and environmental conditions. Field conditions at the time of endophytic application favored the disease development $( \pm 80 \%$ humidity and rainy day, temperature $24-29^{\circ} \mathrm{C}$ in the second 
week of May 2019). This result was confirmed by the earlier studies concerning the abitoc factors of $P$. palmivora's growth and development. Zoospores of $P$. palmivora require approximately 20-30 minutes of free water on external plant membranes to propagate and enter the plant tissue (Guest 2007) as the optimum temperature for highest mycelial growth of $P$. palmivora ranges from 25-28 ${ }^{\circ} \mathrm{C}$ (Kudjordjie 2015). Moreover, Guest (2007) stated that Phytophthora spp. has a rapid life cycle, complicated disease cycle, zoospore motility, and a remarkable multiplicative ability to cause such a significant disease that is very challenging to be controlled by biological control agents. Nevertheles Guest (2007) also affirmed that antagonistic endophytes propose more guarantee as they are naturally transferred from adult plants to saplings in the natural cocoa plantations.

It is observable that endophytes can affect the disease severity. Specifically, they have been performed to reduce or intensify plant disease severity in functional assays that involve susceptible plants, infectious pathogens, and a favorable abiotic ecosystem (Busby et al. 2016). The relationship of plant-endophyte varies from mutualism to pathogenicity. Endophytes can possess neutral or harmful outcomes to the host plant under natural growth circumstances, though they can be valuable under more complicated situations or through several phases of the plant life cycle. Abiotic and biotic aspects influenced the effective colonization by endophytes, such as genotypes of plants and microorganisms, ecological situations, and the active web of collaborations within the plant biome (Hardoim et al. 2015; Chitnis et al. 2020). Our field result implied that we are at the very beginning of identifying the association of endophytic fungi- $P$. palmivora of cocoa and more diverse investigation settings would be required for greater understanding into endophyte performing.

In this trial, we did not perform a phytosanitary cleaning as conducted by Mejía et al. 2008, where all infected fruits were eradicated from the plants more than seven months before the fungal endophytes application. Destroying the primary inoculum sources inhibited the transmission of disease among the trees, reducing the production of secondary inoculum and spores' movement from the soil to the canopy (Guest 2007). It is implied that the cleaned farm with no pathogens and debris helps the endophytic fungi to perform their best antagonist activity against plant pathogen. This experiment was conducted in a small-scale plantation with a lack of sanitation, no pruning and weed control, inappropriate removal of pod mummies and diseased pods. This condition had provided a high inoculum level of P. palmivora, and the endophytic fungi did not have time to establish and protect the plant from the pathogen. This result was in agreement with the study from Hanada et al. (2009), which revealed that the utility of biocontrol organisms is connected to their ability to multiply and persist on the hosts for an extended time after treatment. On the other hand, Hanada et al. 2010 indicated that the grownup pods are possible no longer under the plant's systemic resistance fortification. This condition possibly assists an asymptomatic endophytic fungus to develop an aggressive rot-causing microorganism. This result suggested that the application of fungal endophytes to cocoa trees should be done more than once, from vegetative to generative phases. Besides, Guest 2007 confirmed that fungal endophytes ultimately vanish from the farms, so re-applied them into cocoa continue and secure tree against Phytophthora. Also, our screen house results suggested that fungal endophytes application in plants should be conducted before the arrival of pathogens. The capability of antagonists to multiply within a short period of favorable environmental conditions before confronting plant pathogens is an important factor that increases their efficacy in the field. Also, Mmbaga et al. (2018) claimed that plant inoculation with endophytes prior to the pathogens was more effective than introducing the pathogen before the endophytes.

Investigation on endophytic fungal population has been carried out in few plants (Gouda et al. 2016; Fadiji and Babalola 2020b). Hence, any studies or exploration or data regarding endophytic microorganisms-host relationship is worthy in this research. Additional taxonomic features on the five fungal endophytes relations with the plant are undoubtedly needed. Besides, the improvement of successful biological control approaches relies on diagnosing the relationship of plant endophyte pathogen, which is correlated to validating endophyte habits, settlement model, and spread mode (De Silva et al. 2019). Thus endophytes offer valuable natural resources for potential application as biocontrol agents.

Table 4. Disease severity of black pods before and four weeks after application of endophytic fungi.

\begin{tabular}{lcc}
\hline Endophytic fungi & $\begin{array}{c}\text { Disease severity } \\
\text { before the } \\
\text { application of } \\
\text { endophytic fungi* } \\
\text { (\%) }\end{array}$ & $\begin{array}{c}\text { Disease severity } \\
\text { after the } \\
\text { application of } \\
\text { endophytic fungi* } \\
\text { (\%) }\end{array}$ \\
\hline Control & 0 & 20 \\
Control & 0 & 48 \\
Control & 0 & 36 \\
Control & 0 & 25 \\
Control & 0 & 42 \\
Aspergillus 4 & $>10 \leq 25$ & 50 \\
Aspergillus5 & $>10 \leq 25$ & 50 \\
Aspergillus6 & $>10 \leq 25$ & 80 \\
Fusarium6 & $>10 \leq 25$ & 38 \\
Ramichloridium $\mathrm{sp.}$ & $>10 \leq 25$ & 50 \\
Aspergillus 4 & $>25<50$ & 42 \\
Aspergillus 5 & $>25<50$ & 80 \\
Aspergillus6 6 & $>25<50$ & 70 \\
Fusarium6 & $>25<50$ & 80 \\
Ramichloridium $\mathrm{sp.}$ & $>25<50$ & 60 \\
Aspergillus 4 & $\geq 50$ & 80 \\
Aspergillus 5 & $\geq 50$ & 92 \\
Aspergillus6 & $\geq 50$ & 90 \\
Fusarium6 & $\geq 50$ & 100 \\
Ramichloridium $\mathrm{sp}$. & $\geq 50$ & 100 \\
\hline
\end{tabular}




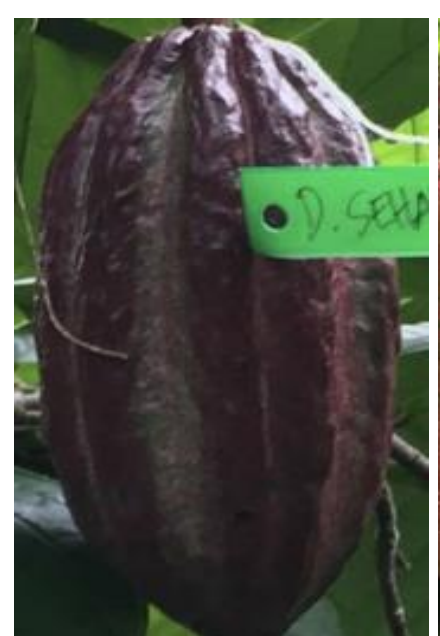

Control

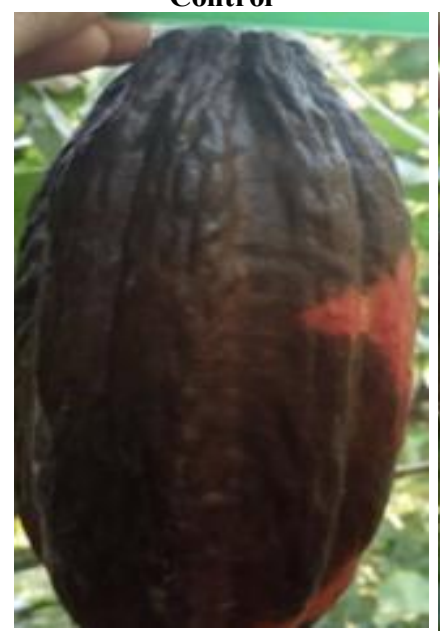

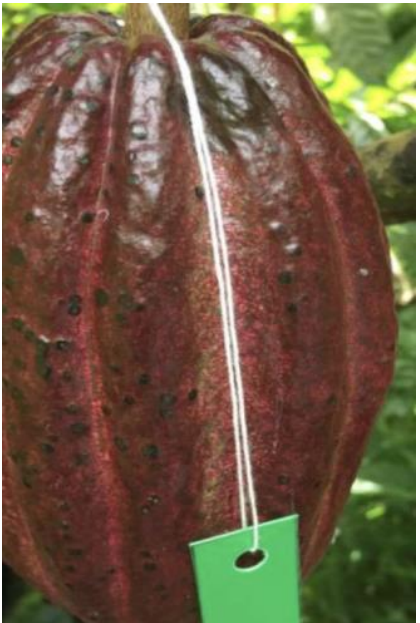

$>10 \leq 25$

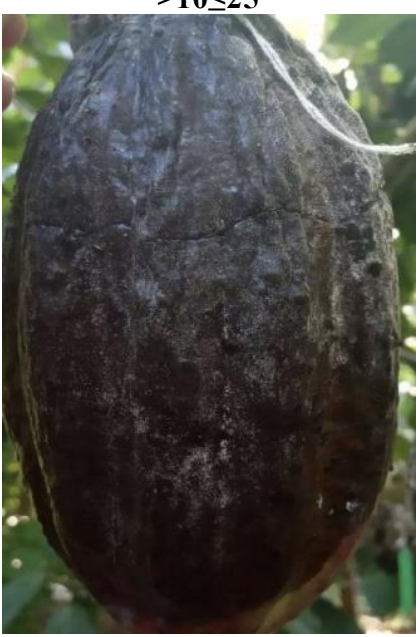

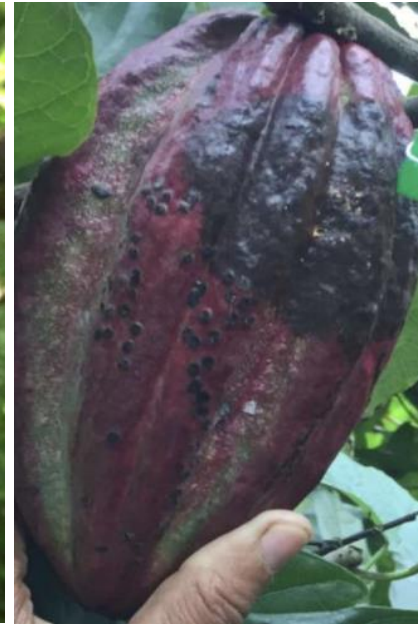

$>25<50 \%$

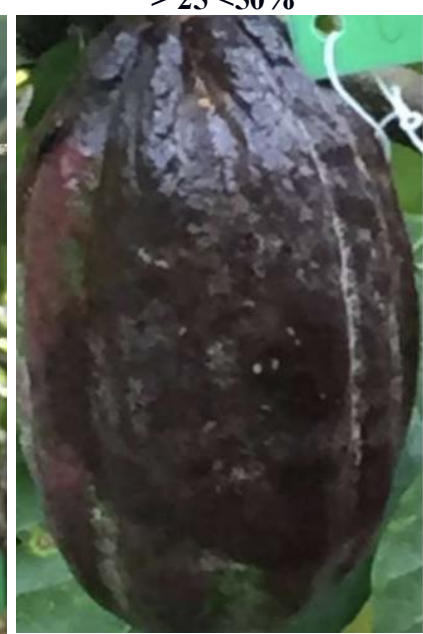

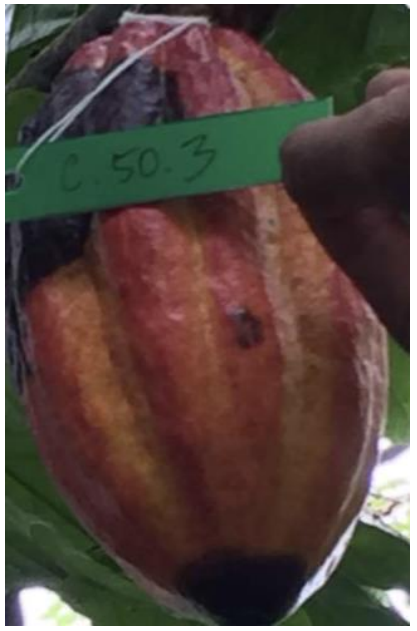

$\geq 50 \%$.

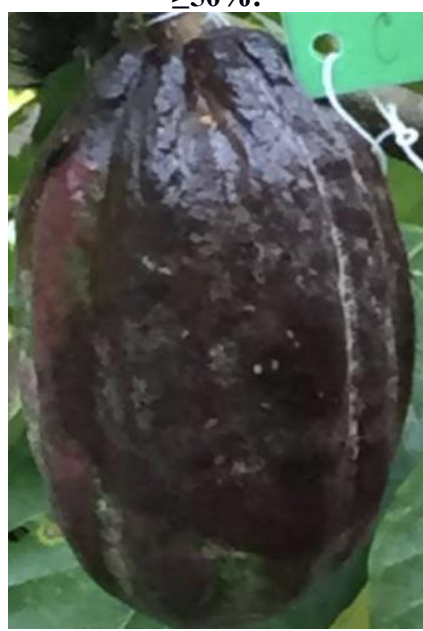

Figure 4. Disease severity of cocoa pods before (first row) and four weeks (second row) after application of endophytic fungi

This study suggested that the Aspergillus4, Aspergillus5, Aspergillus6, Fusarium6, and Ramichloridium sp. can be used to control cocoa black pod disease caused by $P$. palmivora. Different fungal endophytes exhibited potential as biocontrol agents against $P$. palmivora in dual culture, pod, and seedlings assays in the present experiment. However, these assays' result was not found effective in disease suppression on plants in the field. Further research on the application of endophytic fungi in the field needs consideration of phytosanitary aspects and the quantity of endophyte treatment.

\section{ACKNOWLEDGMENTS}

The authors are grateful to the Ministry of Research, Technology and Higher Education Republic of Indonesia (Kemenristekdikti) for funding this research project (Hibah Penelitian Dasar Unggulan Perguruan Tinggi 2018-2019, Contract number: $81 / \mathrm{UN} 15.19 / \mathrm{LT} / 2018)$ ). Thank also to Saptarina Sulla and Guria Robinson Seo for help in the lab works and field trial.

\section{REFERENCES}

Abdallah RAB, Khiareddine HJ, Trabelsi BM, Remadi MD. 2015. Soilborne and compost-borne Aspergillus species for biologically controlling post-harvest diseases of potatoes incited by Fusarium sambunicum and Phytophthora erythroseptica. J Plant Pathol Microbiol 6:10. DOI: 10.4172/2157-7471.1000313.

Abo Nouh FA. 2019. Endophytic fungi for sustainable agriculture. Microb Biosyst 4 (1): 31-44. DOI: 10.21608/mb.2019.38886

Barnett HL, Hunter BB. 1998. Illustrated Genera of Imperfect Fungi. $4^{\text {th }}$ ed. APS Press, St. Paul, USA.

Busby PE, Ridout M, Newcombe G. 2016. Fungal endophytes: modifiers of plant disease. Plant Mpl Biol 90: 645-655. DOI: 10.1007/s11103015-0412-0

Chitnis VR, Suryanarayanan TS, Nataraja KN, Prasad R, Oelmüller R, Shaanker RU. 2020. Fungal endophytes-mediated crop improvement: the way ahead. Front Plant Sci 11: 561007. DOI: $10.3389 /$ fpls.2020.561007.

de Lamo FJ, Takken FLW. 2020. Biocontrol by Fusarium oxysporum using endophyte-mediated resistance. Front Plant Sci 11: 1-15. DOI: 10.3389/fpls.2020.00037.

De Silva N, Brooks S, Lumyong S, Hyde KD. 2019. Use of endophytes as biocontrol agents. Fungal Biol Rev 33: 133-148. DOI: 10.1016/j.fbr.2018.10.001.

El-hawary SS, Moawad AS, Bahr HS, Abdelmohsen UR, Mohammed R. 2020. Natural product diversity from the endophytic fungi of the genus Aspergillus. R Soc Chem Adv 10: 22058-22079. DOI: 10.1039/D0RA04290K. 
Fadiji AE, Babalola OO. 2020a. Elucidating mechanisms of endophytes used in plant protection and other bioactivities with multifunctional prospects. Front Bioeng Biotechnol 8: 467. DOI: 10.3389/fbioe.2020.00467.

Fadiji AE, Babalola OO. 2020b. Exploring the potentialities of beneficial endophytes for improved plant growth. Saudi J Biol Sci 27: $3622-$ 3633. DOI: $10.1016 /$ j.sjbs.2020.08.002

Fitriarni D, Kasiamdari RS. 2018 Isolation and identification of endophytic fungi from leave and stem of Calopogonium mucunoides. J Trop Biodivers Biotechnol 3: 30-36. DOI: 10.22146/jtbb.32477.

Gassa A, Mulia S, Yumarto, Junaid M. 2016. Phytophthora black pod disease of cocoa caused by Phytophthora palmivora: development of bio-fungicidal package in controlling the disease and the vector by food bait. J Chem Pharm Res 8 (6): 129-125.

Gautam AK, Kant M, Thakur Y. 2013. Isolation of endophytic fungi from Cannabis sativa and study their antifungal potential. Arch Phytopathol Plant Protect 46: 627-635. DOI: 10.1080/03235408.2012.749696

Guest D. 2007. Black Pod: Diverse pathogens with a global impact on cocoa yield. Phytopathology 97: 1650-1653. DOI: 10.1094/PHYTO 97-12-1650

Gouda S, Das G, Sen SK, Shin HS, Patra JK. 2016. Endophytes: a treasure house of bioactive compounds of medicinal importance. Front Microbiol 7: 148. DOI: 10.3389/fmicb.2016.01538.

Hanada RE, Pomella AWV, Costa HS, Bezerra JL, Loguercio LL, Pereira HS. 2010. Endophytic fungal diversity in Theobroma cacao (cacao) and $T$. grandiflorum (cupuacu) trees and their potential for growth promotion and biocontrol of black-pod disease. Fungal Biol 114: 901910. DOI: 10.1016/j.funbio.2010.08.006.

Hanada R, Pomella AWV, Soberanis W, Loguercio LL, Pareira JO. 2009 Biocontrol potential of Trichoderma martiale against the black-pod disease (Phytophthora palmivora) of cacao. Biol Control 50: 143-149. DOI: 10.1016/j.biocontrol.2009.04.005.

Hardoim PR, Van Overbeek LS, Berg G, Pirttilä AM, Compant S, Campisano A, Döring M, Sessitsch A. 2015. The hidden world within plants: ecological and evolutionary considerations for defining functioning of microbial endophytes. Microbiol Mol Biol Rev 79 (3): 293-320. DOI: 10.1128/MMBR.00050-14.

Harni R, Taufiq E, Amaria W. 2014. Pengaruh formula fungisida nabati minyak cengkeh dan serai wangi terhadap penyakit busuk buah kakao. Jurnal Tanaman Industri dan Penyegar 1 (1): 41-48. DOI: 10.21082/jtidp.v1n1.2014.p41-48. [Indonesian]

Jain P. Pundir RK. 2017. Potential role of endophytes in sustainable agriculture-recent development and future prospects. In: Maheshwari K (eds) Endophytes: Biology and biotechnology, sustainable development and biodiversity 15: 145-160. Springer International Publishing AG, Swizterland. DOI: 10.1007/978-3-319-66541-2_7.

Kirschner R, Piepenbring M. 2014. New records of three Ramichloridium species on banana leaves in Panama and Taiwan. Mycoscience 55 (4) 260-267. DOI: 10.1016/j.myc.2013.10.002

Kudjordjie EN. 2015. Phytophthora megakarya and P. palmivora on Theobroma cacao: Aspects of virulence and the effects of temperature on growth and resistance to fungicides. [Master's thesis]. Faculty of Science, University of Copenhagen, Denmark.

Lugtenberg BJJ, Caradus JR, Johnson LJ. 2016. Fungal endophytes for sustainable crop production. FEMS Microbiol Ecol 92. DOI: 10.1093/femsec/fiw194.

Mejía LC, Rojas EI, Maynard Z, Van Bael S, Arnold AE, Hebbar P, Samuels GJ, Robbins N, Herre EA. 2008. Endophytic fungi as biocontrol agents of Theobroma cacao pathogens. Biol Control 46 (1): 4-14. DOI: 10.1016/j.biocontrol.2008.01.012.

Mmbaga MT, Gurung S, Maheshwari A. 2018. Screening of plant endophytes as biocontrol agents against root rot pathogens of peppe (Capsicum annum L.). J Plant Pathol Microbiol 9:3. DOI: 10.4172/2157-7471.1000435

Myrchiang P, Dkhar MS, Haoboam RD. 2014. Studies on fungi associated with medicinally important aromatic plant Artemisia nilagirica (C.B. Clarke) Pamp. and their antagonistic activity against Phytophthora infestans. J Adv Lab Res Biol 5 (4): 112-119.

Nur'Aini F, Santoso TI, Sudarsianto S. 2016. Application of copper fungicide and row covers to control Phytophthora seedling blight disease on cocoa. Pelita Perkebunan 32 (2): 101-108. DOI: 10.22302/iccri.jur.pelitaperkebunan.v32i2.221 [Indonesian]

Nur Amin. 2013. Investigation of culture filtrate of endophytic fungi Nigrospora sp. isolate RS 10 in different concentrations towards root- knot nematode Meloidogyne spp. Indian J Sci Technol 6 (9): 5177 5181. DOI:10.17485/ijst/2013/v6i9.1.

Nur Amin, Muslim S, Junaid M, Baco MS. 2014. Isolation and identification of endophytic fungi from cocoa plant resistance VSD M.05 and cocoa plant susceptible VSD M.01 in South Sulawesi, Indonesia. Int J Curr Microbiol App Sci 3 (2): 459-467.

Nur Amin, Muslim S, Asman, Ryan, Danial R. 2015. Investigation of fungi towards vascular streak dieback Oncobasidium theobromae of seedling od cocoa plant. J Appl Biol Sci 9 (2): 86-89.

Olokkaran R, Mathew S, Alakkatt J, Sunny SK. 2019. Isolation and morphological identification of aflatoxigenic Aspergillus flavus in finished feed for farmed Nile tilapia, Oreochromis niloticus (Linnaeus, 1758). Int J Fish Aquat Stud 7 (6): 280-286.

Perrine-Walker F. 2020. Phytophthora palmivora-Cocoa interaction. J Fungi 6: 167. DOI: 10.3390/jof6030167.

Peter PK, Chandramohanan R. 2014. Management of cocoa seedling blight caused by Phytophthora palmivora. Plant Arch 14 (1):461-463.

Peters LP, Prado LS, Silva FIN, Souza FSC, Carvalho CM. 2020. Selection of endophytes as antagonists of Colletotrichum gloeosporioides in açaí palm. Biol Control 150: 104350. DOI: 10.1016/j.biocontrol.2020.104350

Praseptiangga D, Guevara Zambrano JM, Sanjaya AP, Muhammad DRA. 2020. Challenges in the development of the cocoa and chocolate industry in Indonesia: A case study in Madiun, East Java. AIMS Agric Food 5 (4): 920-937. DOI: 10.3934/agrfood.2020.4.920.

Rashmi M, Kushveer JS, Sarma VV. 2019. A worldwide list of endophytic fungi with notes on ecology and diversity. Mycosphere 10 (1): 798-1079. DOI: $10.5943 /$ mycosphere/10/1/19.

Rubiyo, Amaria D. 2013. Ketahanan tanaman kakao terhadap penyakit busuk buah (Phytophthora palmivora Bult.). Balai Penelitian Tanaman Industri dan Penyegar $12: 25-36$. [Indonesian]

Sella PG, Fardah. 2020. Indonesia earns US\$549 million from processed cocoa exports. https://en.antaranews.com/news/158489/indonesiaearns-us549-million-from-processed-cocoa-exports.

Sriwati R, R Muarif. 2012. Characteristic symptoms of Phytophthora palmivora on cocoa leaves. Jurnal Natural 12 (2) : 30-34. [Indonesian]

Sriwati R, Melnick RL, Muarif R, Strem MD, Samuels GD, Bailey BA. 2015. Trichoderma from Aceh Sumatra reduces Phytophthora lesions on pods and cacao seedlings. Biol Control 89: 33-41. DOI: 10.1016/j.biocontrol.2015.04.018

Stinson M, Ezra D, Hess WM, Sears J, Strobel G. 2003. An endophytic Gliocladium sp. of Eucryphia cordifolia producing selective volatile antimicrobial compounds. Plant Sci 165 (4): 913-922. DOI: 10.1016/S0168-9452(03)00299-1

Villamizar-Gallardo RA, Ortiz-Rodriguez OO, Escobar JW. 2017. Symbiotic and endophytic fungi as biocontrols against cocoa (Theobroma cacao L.) Phytopathogens. Summa Phytopathol 43 (2): 87-93. DOI: $10.1590 / 0100-5405 / 2175$.

Vyas P, Bansal A. 2018. Fungal endophytes: role in sustainable agriculture. In: Gehlot, Praveen, Singh, Joginder (eds) Fungi and their Role in Agriculture. Springer Singapore. DOI: 10.1007/978-981-130393-7.

Wardhany M, Adzim F. 2018. Determinant of cocoa export in Indonesia. Econ Dev Anal J 7 (3): 286-293. DOI: 10.15294/edaj.v7i3.25262

Watanabe T. 2010. Pictorial atlas of soil and seed fungi. Morphologies and cultured fungi and key to species. $3^{\text {rd }}$ ed. CRC Press, Boca Raton, FL.

Wei F, Zhang Y, Shi Y, Feng H, Zhao L, Feng Z, Zhu H. 2019. Evaluation of the biocontrol potential of endophytic fungus Fusarium solani CEF559 against Verticillium dahliae in cotton plant. Hindawi. Biomed Res Int article ID 3187943. DOI: 10.1155/2019/3187943.

Witjaksono J, Asmin. 2016. Cocoa farming system in Indonesia and its sustainability under climate change. Agric For Fish 5 (5): 170-180. DOI: 10.11648/j.aff.20160505.15

Xie L, Usui E, Narisawa K. 2016. A endophytic fungus, Ramichloridium cerophilum, promotes growth of a non-mycorrhizal plant, Chinese cabbage. Afr J Biotechnol 15 (25): 1299-1305. DOI: 10.5897/AJB2016.15398

Zheng H, Zefen Yu, Jianping Xu, Castañeda-Ruiz RF, Min Qiao. 2020. Ramichloridium endophyticum sp. nov., a novel species of endophytic fungus from Potamogeton pectinatus. Int J Syst Evol Microbiol 70 (5): 1-7. DOI: 10.1099/ijsem.0.004190. 